\title{
Mapping Submarine Landslide: A Case Study in Northern Continental Slope of the South China Sea
}

\author{
Tianyun $\mathrm{Su}^{1, *}$, Xishuang $\mathrm{Li}^{1}$, Jiagang $\mathrm{Li}^{2}$ and Lejun $\mathrm{Liu}^{1}$ \\ ${ }^{1}$ First Institute of Oceanography, SOA, Qingdao, 266061, China; ${ }^{2}$ Research Center of China National Offshore Oil \\ Corporation, Beijing, 100027, China
}

\begin{abstract}
Geographical Information Systems is a useful tool for marine geohazard mapping. This paper describes an integrated and systematic map-based approach for identification and characterization of submarine landslide with multidisciplinary data such as multibeam bathymetric data, multichannel seismic data, sidescan sonar and so on. Taking Liwan 31 gas field in northern continental slope of Southern China Sea as a case study, a regional database is established to provide convenient services to manage search and extract the target data for geohazard mapping and identification. Bathymetric map and seismo-geomorphologic map are calculated and produced with GIS to establish an elementary understanding of geomorphologic features. With this integrated approach, dozens of landslides are identified in the study area and they are featured as small and multiple superimposed failure scars. Fundamental information of landslides can also be provided for further detail interpretation, quantification and assessment of their mechanism and potential risks.
\end{abstract}

Keywords: Geographic information system (GIS), morphometric map, multibeam bathymetry, submarine landslide, South China Sea.

\section{INTRODUCTION}

Over the last decade, exploration and development of offshore hydrocarbon resources has advanced into remote deepwater regions and poses significant technical challenges for the design and installation of wells and facilities at extreme water depths. In the deepwater hydrocarbon resources regions, sediment is usually featured as thick, high deposition rate, excess pore fluid pressure and low soil strength. So, the exploration and exploitation of deep-water oil\&gas are apt to be suffered from high-risk geohazards such as submarine landslide, soft clay creep, shallow gas, excess pore-water pressure, mud volcano or mud diaper, salt dome and so on. More and more concerns about deep-water geohazards have been raised by the increasing amount of offshore hydrocarbon resources exploration and production and careful evaluation and mitigation are required during the front-end planning and engineering design stages of projects.

The primary challenge in studying deepwater geohazard is the relative inaccessibility and invisibility of the submarine environment. The only way to know where and when a submarine slide has occurred is to have multi-disciplinary data before and after a slide [1]. The data include multi-beam bathymetry data, sidescan sonar images, seismic data, shallow-bottom profiling images, boring data, etc., which nowadays increase rapidly to large amounts with heterogeneous formats and have different resolutions. It is difficult to make good management and utilization of such submarine data with traditional means.

\footnotetext{
*Address correspondence to this author at the No.6 Xian Xialing Road, Qingdao, China. Postcard: 266061; Tel: +86 532 88967957;

E-mail: tianyun.su@gmail.com
}

Geographical Information Systems (GIS) technology can provide efficient and powerful tools or services in such aspects as spatial data management, processing, analysis and visualization. The integrated approach to the systematic mapping of seafloor geomorphology with GIS technology is becoming fundamental to underpinning qualitative and/or quantitative geohazard risk assessment for development and engineering proposals [2-9].

The multi-disciplinary and heterogeneous marine geohazard data, in digital format, are ideally suited for storage, compilation, spatial analysis and visualization in a GISbased framework (Fig. 1). and can be further interpreted to provide critical information on the location, distribution, susceptibility, vulnerability and probability associated with marine geohazards.

As a case study to apply the presented integrated approach to map and assess the marine geohazard, we typically focus on Liwan 3-1Gas Field, which is located in the Zhu II Depression in the Zhujiang Basin and the front of continental slope of the northern South China Sea. As part of team work, this study, with GIS technology, attempts to map and identify the elementary morphology of geohazard features, especially landslides, before detail interpretation, quantification and assessment of the mechanism and potential risks in $\mathrm{Li}$ wan 3-1 gas field region.

\section{STUDY AREA}

The South China Sea is the largest marginal basin in the western Pacific Ocean and lies at the junction of the Eurasian plate, the Indian-Australian plate and the Pacific plate [10]. Many researches have reported that the potential geohazards, such as active sand wave/sand hill, pockmark, landslide, scarp, abrupt slope, submarine canyon, paleo-channel, 


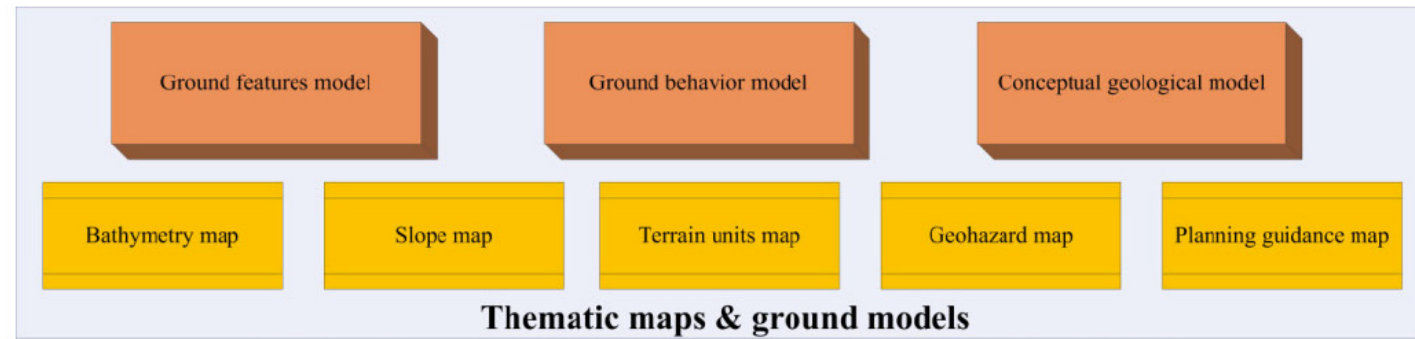

\section{Thematic maps \& ground models}

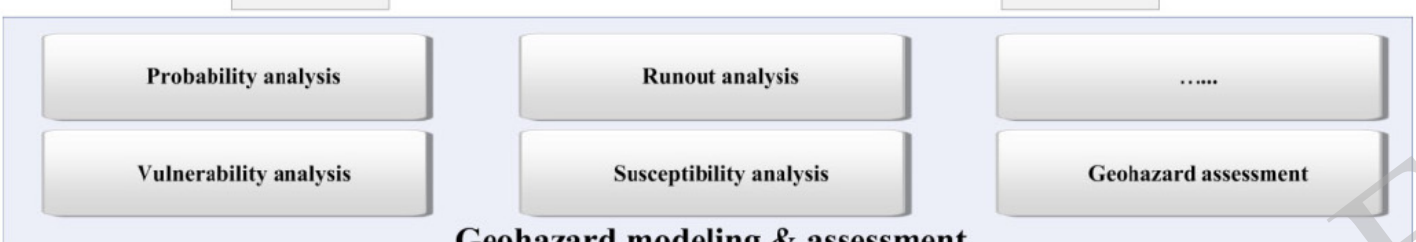

Geohazard modeling \& assessment
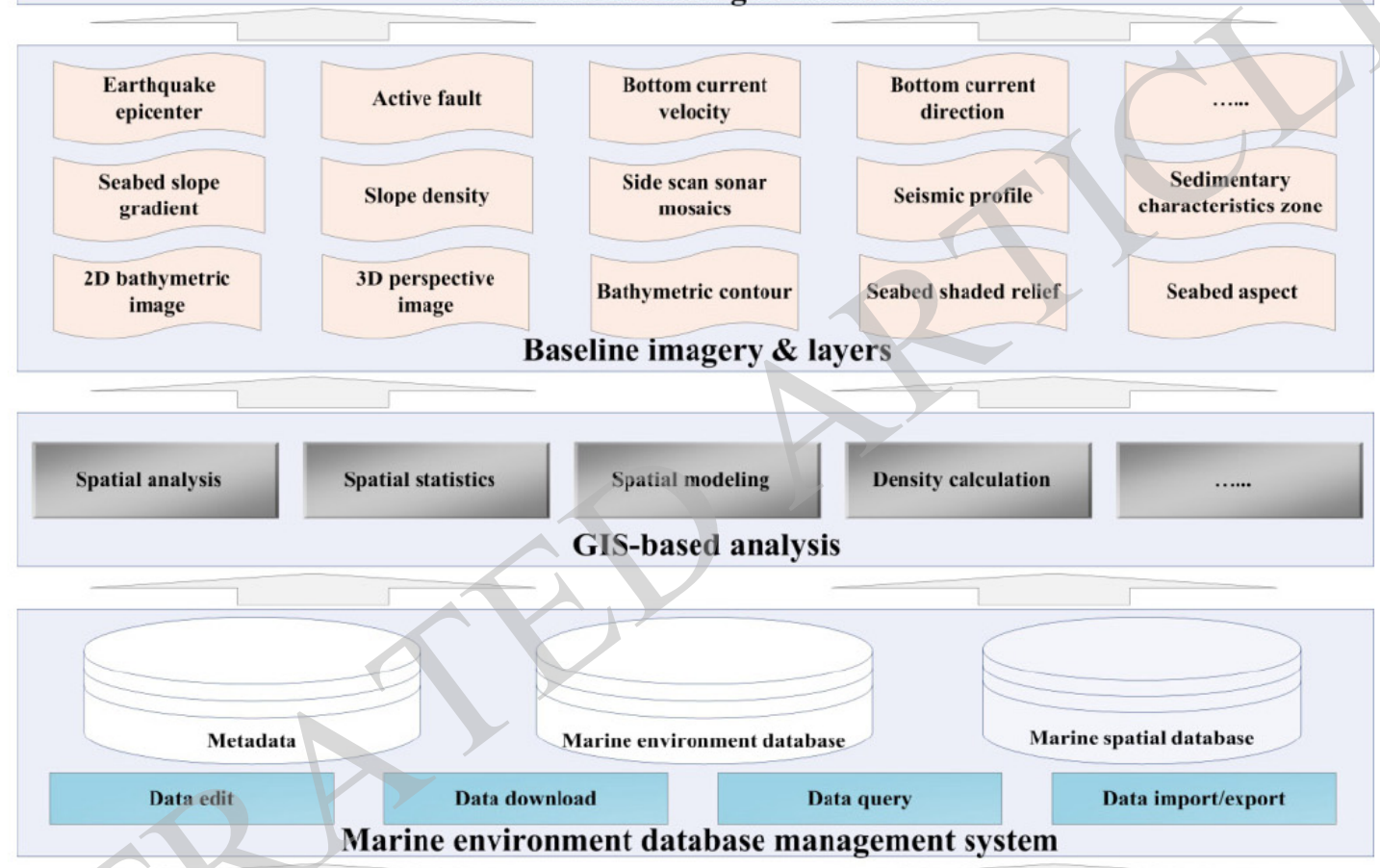

Marine environment database management system

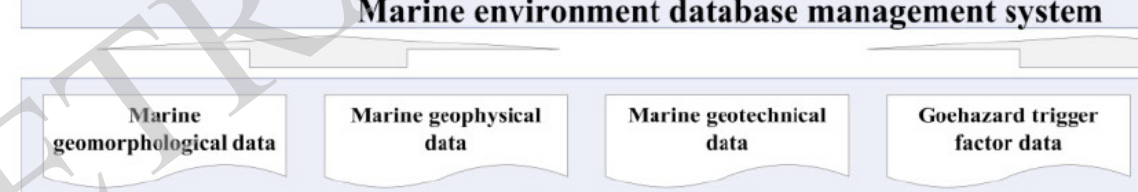

Marine environment data for geohazard assessment

Fig. (1). Flow diagram of GIS-based marine geohazard assessment.

shallow gas and diaper, are present on the shelf and the slope of the northern South China Sea [11-13]. As for the Pearl River Mouth Basin, there are also several kinds of unfavorable geological bodies, such as large seafloor landslides in the Baiyun Depression [14], and mud volcano, seafloor landslide and shallow gas in the outer shelf [15].

As showed in Fig. (2)., the study area, $300 \mathrm{~km}$ away from the modern Pearl River estuary, locates in the Baiyun Depression of the Southern Depression Zone. The northern continental slope extends from the slope break belt at $200 \mathrm{~m}$ depth to the area of $3200 \sim 3500 \mathrm{~m}$ depth. It stretches in a NESW direction, paralleling roughly to the coastline. According to the geomorphologic characteristics, the northern continental slope is divided into eastern, middle and western sections.

\section{DATA SOURCES}

To avoid huge economic loss and ecological environmental damage, it is necessary to evaluate the geohazards for the establishment and safe operation of the pipeline. Although, previous researches provided useful regional 


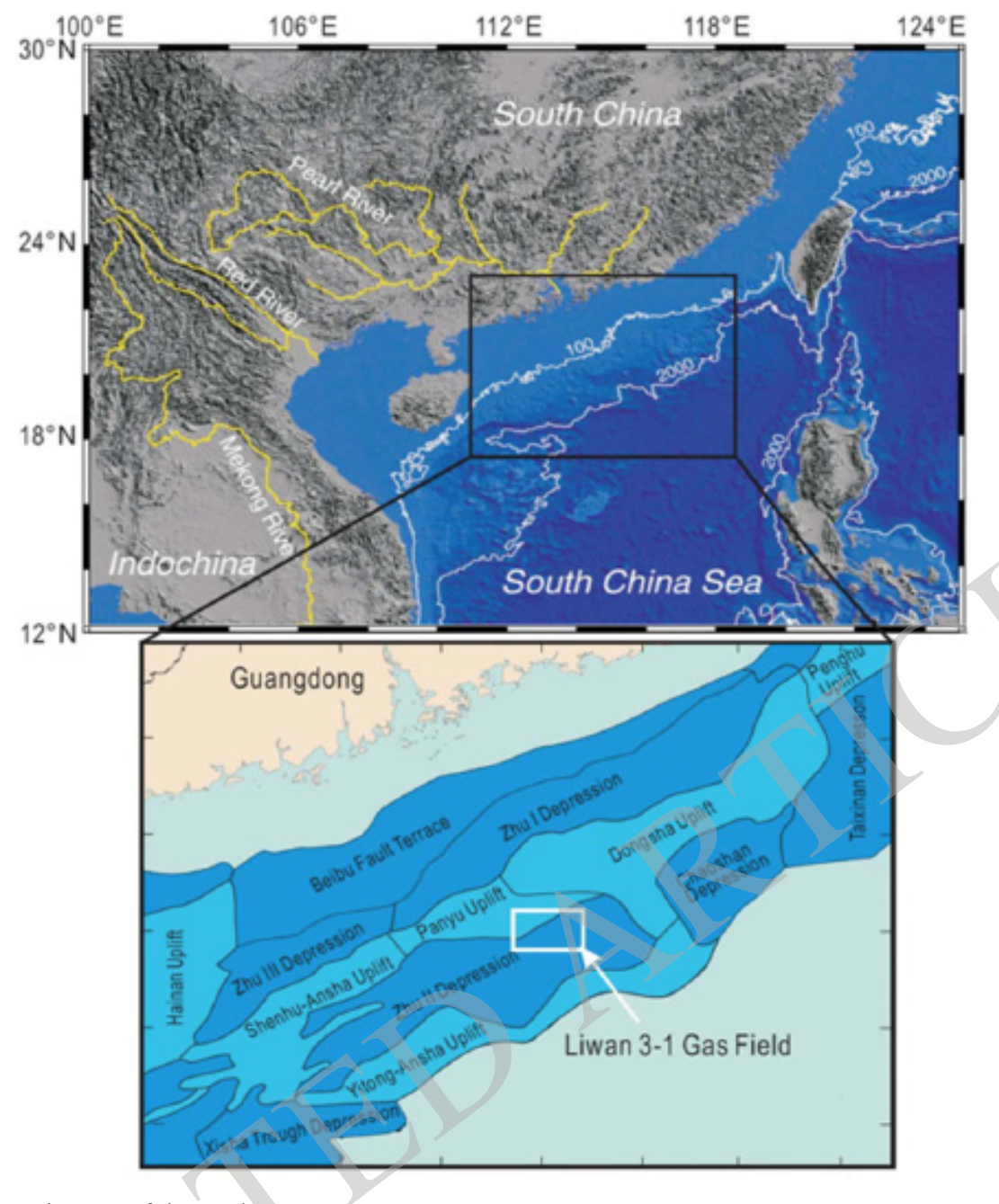

Fig. (2). Geographic and tectonic map of the study area.

background data such as bathymetric data, sub-bottom profiles, side scan sonar data and other high-resolution acoustic data, the resolution and accuracy cannot meet the engineering requirement of offshore hydrocarbon resources exploration and development. Multidisciplinary survey is under implementation around the Liwan 3-1 gas field including multibeam bathymetric survey, shallow-stratum profiling, highresolution multi-channel seismic exploration and AUV investigation.

This study uses shipboard multibeam bathymetrics (MBB), shallow-stratum profiles (SSP), multi-channel seismic (MCS) data, AUV multibeam bathymetrics and sidescan sonar images acquired through a geographic survey on the vessel Nanhan-503 in 2011. MBB data were collected using the EM302 Multi-Beam Bathymetric System and gridded in $20 \mathrm{~m}$ resolution. SSP data for $1500 \mathrm{~km}$ were collected using a hull-mounted TOPAS Shallow-Stratum Profile with a source pulse centre on $3.3 \mathrm{kHz}$. MCS data were collected using a detection system consisting of a $10000 \mathrm{~J}$ plasma sparker, a 120 channel digital cable mounted on the vessel "Shiyan 1" in September, 2010.

SRTM_30 Plus [16] bathymetry data (30 arc seconds resolution) and GEBCO [17] bathymetry data (30 arc seconds resolution) are also used for background supplemen- tary. The final bathymetry grid was complied for regional mapping and further study Fig. (3).

\section{METHOD}

\subsection{Database}

In order to make good use of these precious data, GIS technology is used in our research. Data model is designed to depict the structure, organization and relationship between multidisciplinary submarine data. With these data models, marine geohazard database is established to manage and share the attribute and spatial data effectively.

As showed in Fig. (4), regional marine geohazard database of Liwan 3-1 gas field is designed and constructed. Taking advantage of this database, spatial data of study area such as bathymetric data, sidescan sonar images, shallowstratum profiles and multi-channel seismic data can be searched and extracted conveniently to support the following geohazard mapping and identification.

\subsection{Bathymetric Mapping}

When mapping any geomorphic feature, be it incised steam beds, drumlins, or landslides, it is useful to view the data in a format that accentuates rapid changes in surface 


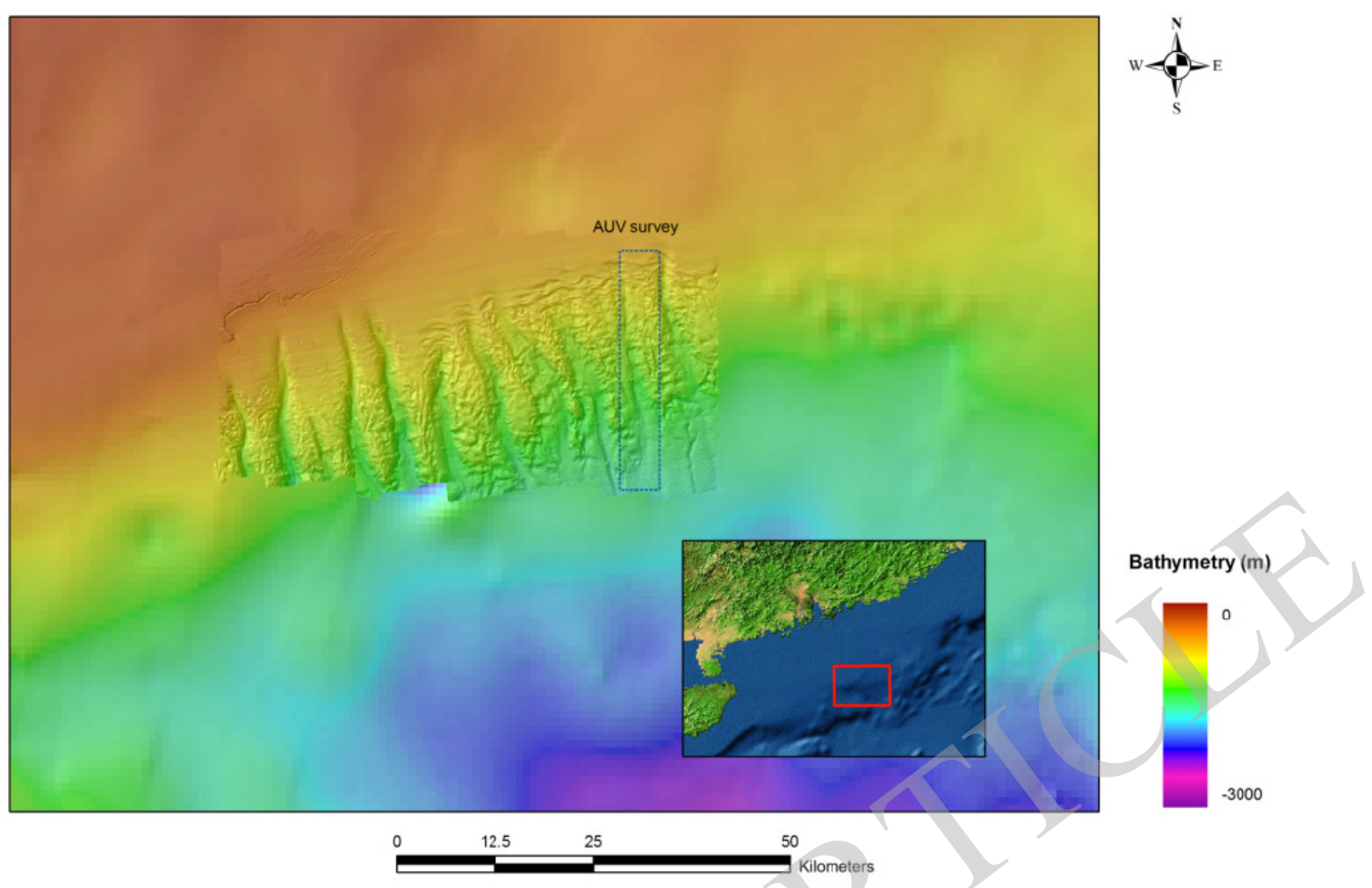

Fig. (3). Bathymetry compilation from from SRTM_30 Plus $\left(30^{\prime \prime} \times 30^{\prime \prime}\right)$ GEBCO $\left(30^{\prime \prime} \times 30^{\prime \prime}\right)$, shipboard multibeam bathymetrics $(20 \mathrm{~m} \times 20 \mathrm{~m})$ and AUV multibeam bathymetrics $(1 \mathrm{~m} \times 1 \mathrm{~m})$.

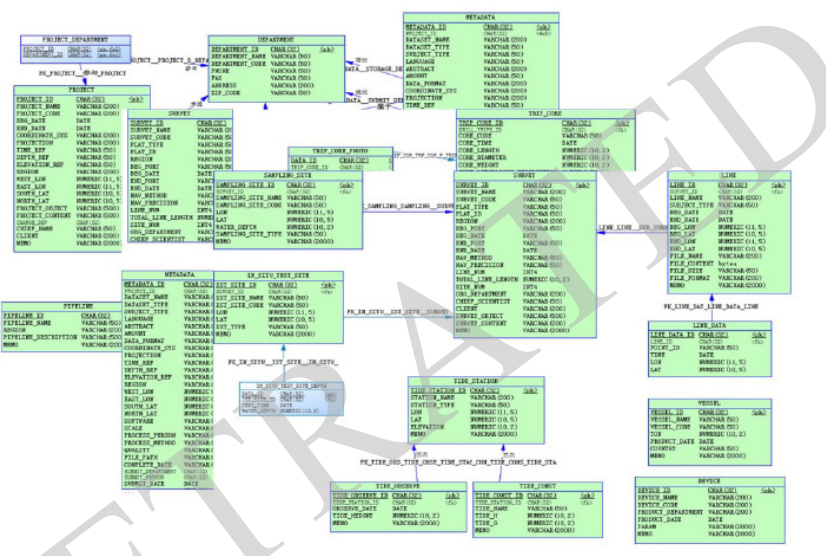

a

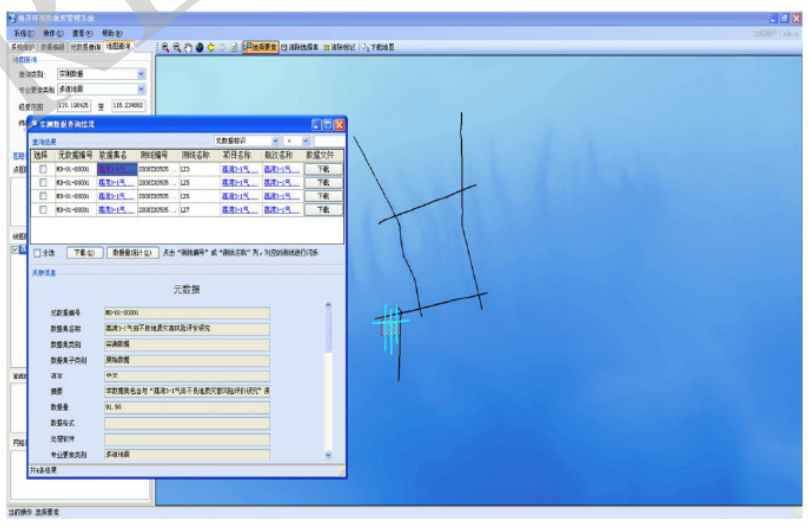

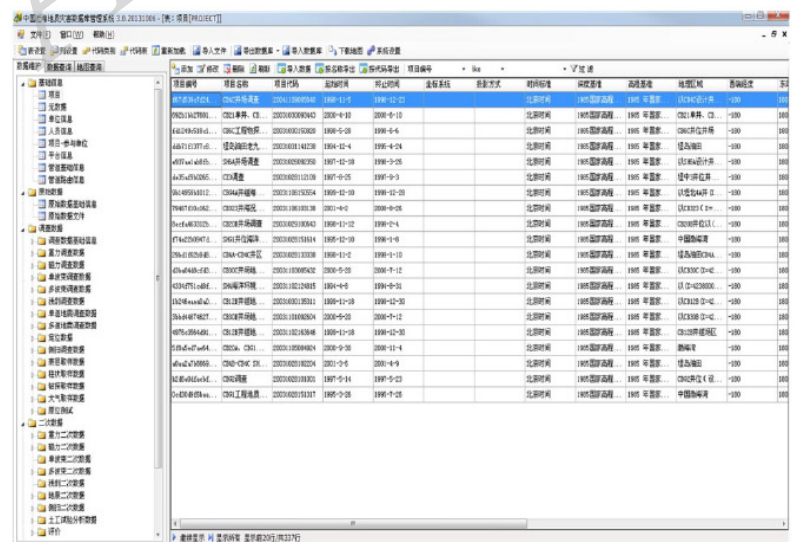

b

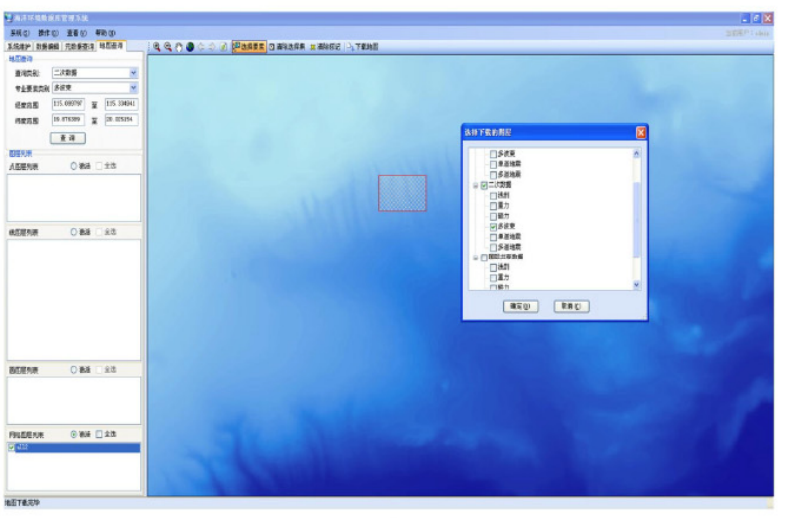

d

Fig. (4). Marine geohazard database. (a) Data models to depict the data structure; (b) Data management system to provide convenient operation of data edition, import \& export; (c) Data query based on survey line; (d) Bathymetric grid extraction based on spatial selection. 
elevation. Multibeam bathymetric data are very useful for a first pass geomorphic mapping and assessment of a marine geohazard. They can provide information on the water depths where failures occur, such as slide thickness, heights from top of the headscarp to base of the scar, runout maximum, height of the headscarp and slide thickness.

Using Arc/INFO 9.3, bathymetry, shaded relief, seabed aspect and seabed slope angle are calculated and mapped for landslide scars identification Fig. (5).

Fig. (5a) shows a section of seabed of Liwan 3-1 Gas Field viewed using shipboard multibeam bathymetric DEM in $20 \mathrm{~m}$ resolution over the hillshaded relief with $100 \mathrm{~m}$ interval contours. From this view, several small submarine canyons arrange closely in the slope where water depth varies from $500 \mathrm{~m}$ to $1700 \mathrm{~m}$ depth. Length of the canyons ranges from 20 to $30 \mathrm{~km}$ and the thalweg spacing is about $6 \sim 7 \mathrm{~km}$.

Fig. (5b) shows a shaded relief with artificial hillshading algorithms. It can cast "shadows" and illuminate regions of steep local slope or bathymetric roughness, such as steep headscarps, sidewalls, and sometimes rubble at the base of the landslide scar, which is helpful for identifying slope failures. From Fig. (5b), about 126 small landslide scars can be recognized, which are marked with red curves.

Aspect maps are helpful in identifying regions of anomalous direction, and highlight regions such as canyons and slides' sidewalls where the erosive walls are directed $\sim 90^{\circ}$ to the headscarp and local downslope trend. This method is useful especially in the area where the slope failures is large and got less corrosion. In Fig. (5c), it is not obvious to identify the anomalous direction features. It reveals that the slope failures in this area are small and eroded by multi-stage small landslides.

Slope gradient map can help identify the diagnostic short wavelength changes (i.e., rapid changes) in bathymetry associated with arcuate headscarps and connected sidewalls [2].
As showed in Fig. (5d), diagnostic arcuate headscarps with extending sub-parallel sidewalls are illuminated by the slope gradient maps. In the study area, seafloor gradient are typically $\sim 5^{\circ}$, but in the steepest parts it can be up to $\sim 25^{\circ}$. The seafloor gradient of headscarps are about $7^{\circ} \sim 15^{\circ}$ and the arcuate features can be verified with those identified from shaded relief Fig. (5b). The main canyons and other erosive features (including regions that possibly have multiple superimposed failure scars) can be excluded for lack of the diagnostic arcutate headscarps.

Additionally, cross-sections or profiles through a slide from bathymetric DEM can help to verify potential landslide surface. Fig. (6) shows two cross-sections of a landslide scar recognized from high resolution $(1 \mathrm{~m} \times 1 \mathrm{~m})$ AUV bathymetry shaded relief. The area of the landslide scar is about 840,000 $\mathrm{m}^{2}$. Headscarps are easily identified from down-slope profile, and profile taken across slides is helpful in identifying the lateral extent of erosion or deposition, and helping constrain the geometry of the slide deposit. The characteristics within the slide scar, like headscarps height, runout distance, headscarps, point of the maximum slope, et al., can also be identified and calculated from cross-sections or profiles.

\subsection{Seismogeomorphological Mapping}

As discussed by McAdoo [1], bathymetric mapping has several known shortfalls in determining some landslides, like smaller, overlapping, older or shallow seated failures. Subsurface data from seismic survey is a good supplementary to reveal landslide features. With uniform coordinate system in GIS, the survey line of seismic profile can be located on the bathymetry map and help establish spatial relationship with seabed geomorphology. This provides a mean of integrating data on seabed geomorphology interpreted from bathymetry, with sub-seabed geological data interpreted from seismic data, to give a three dimensional understanding of geohazard processes.

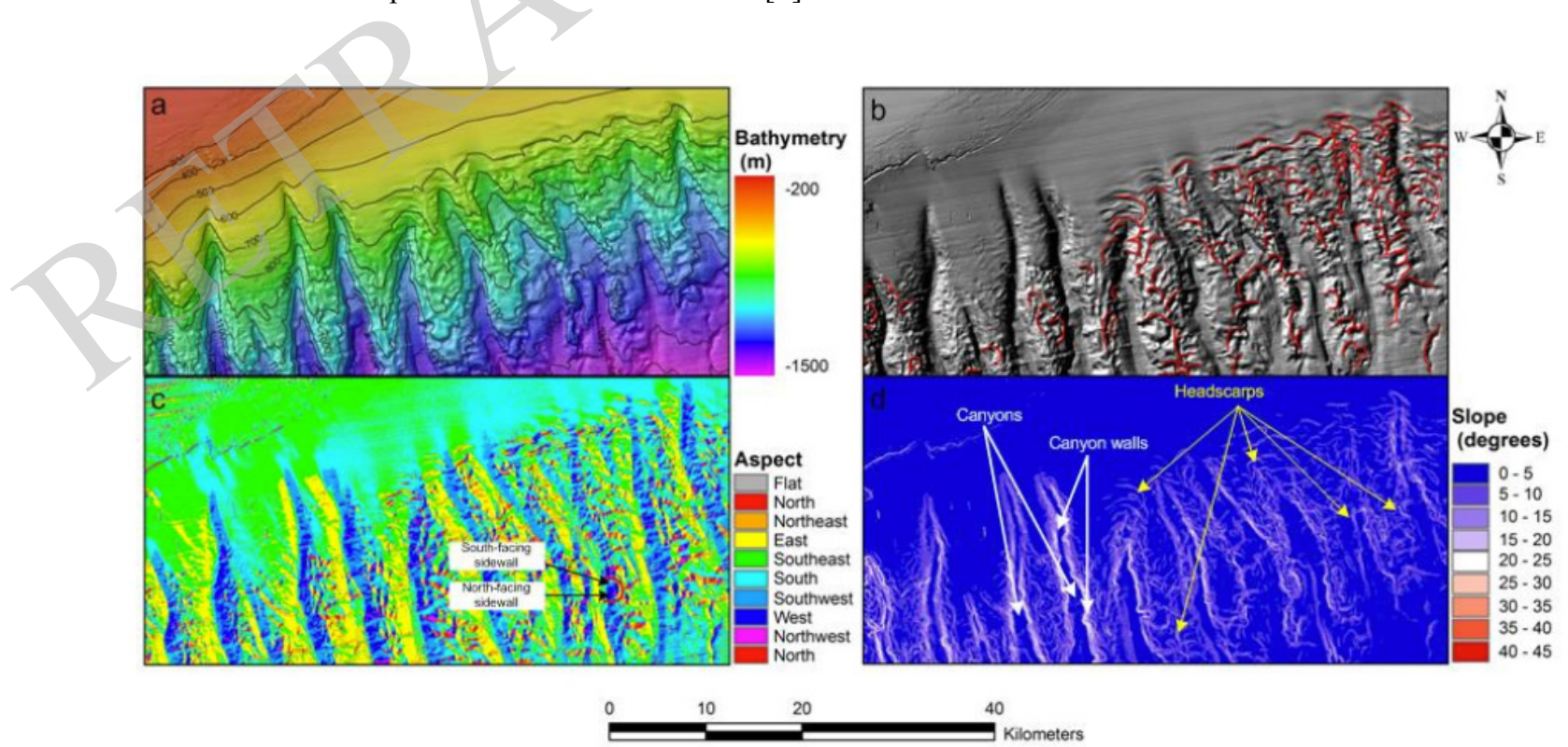

Fig. (5). Bathymetic map of the study area. (a) Bathymetry; (b) Shaded relief illuminated with an azimuth of $315^{\circ}$ and a $45^{\circ}$ inclination; (c) Aspect. N, NE, E, etc. represent compass directions north, northeast, east, etc.; (d) Slope gradient with lighter shading for higher gradients and darker for lower. 

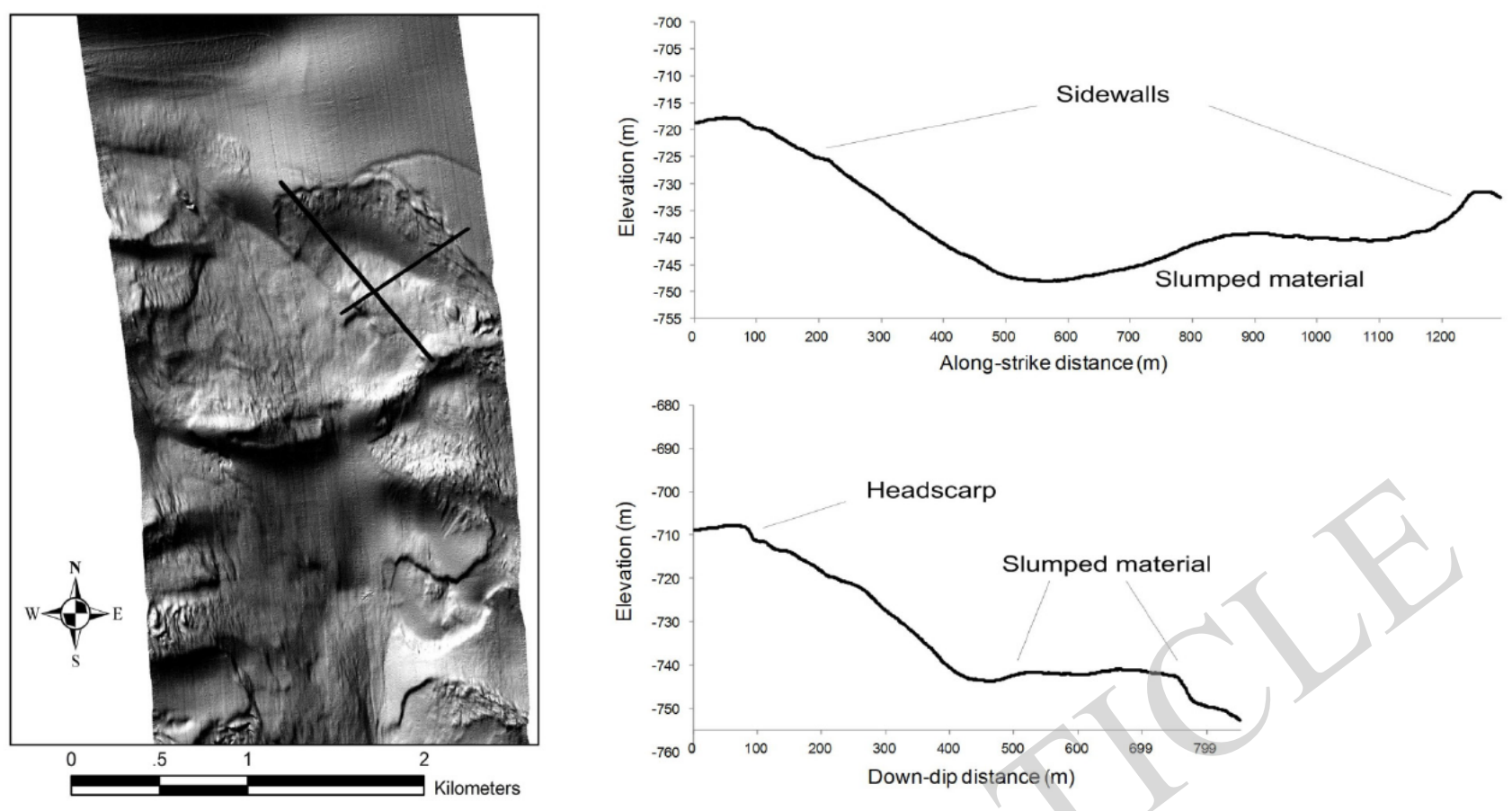

Fig. (6). Cross-sections parallel to a slide's headscarp and down slope.

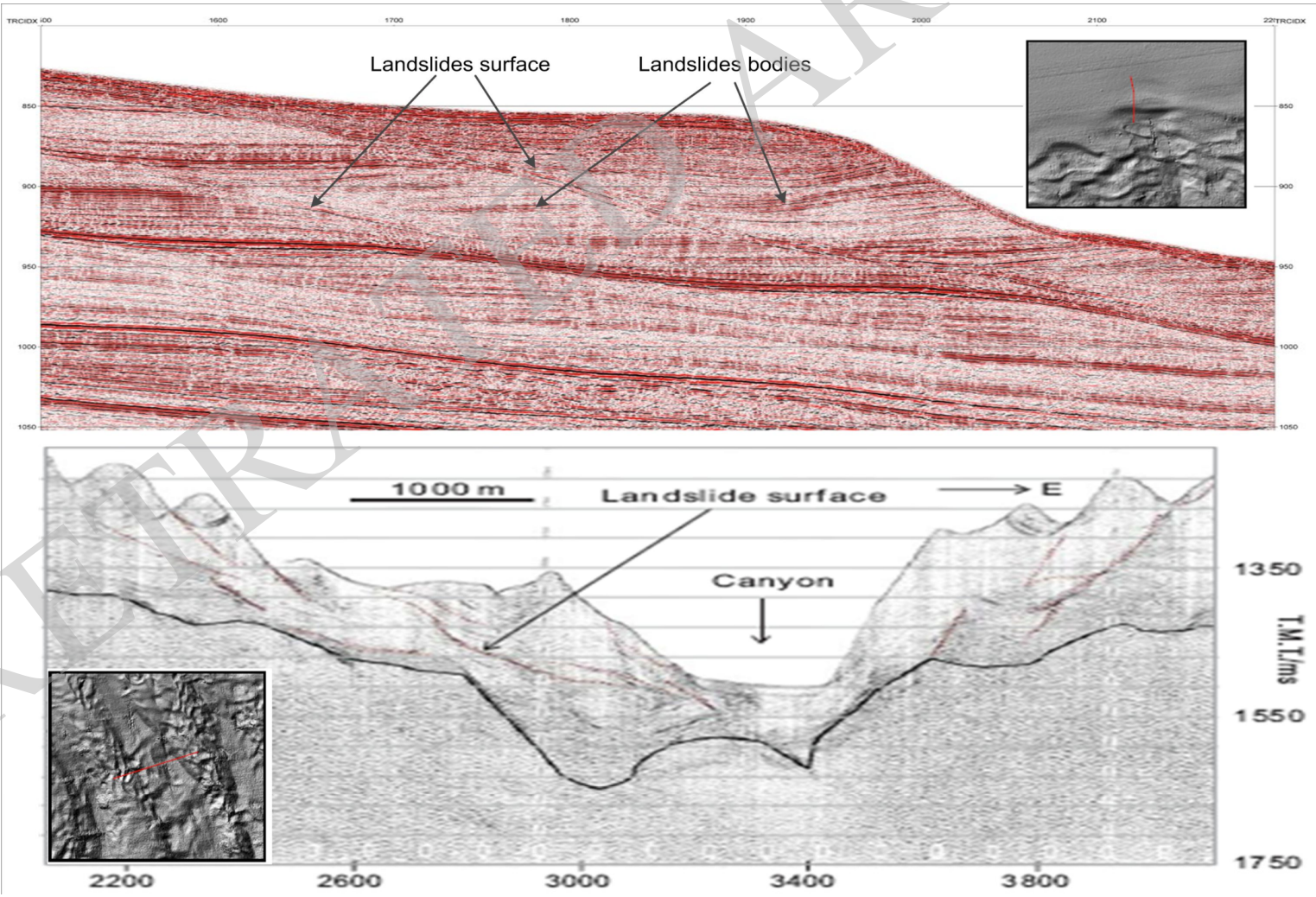

Fig. (7). Part of multichannel seismic profiles with survey lines located in inset map.

In this study, two multi-channel seismic profiles Fig. (7) in study area are illustrated with survey line located on bathymetric map and seabed geomorphologic features, in order that typical landslides and canyon system can be identified. As showed in Fig. (7), the seismic reflection reveals small and overlapping deposits from landslides which are difficult to be identified from bathymetric map.

\section{CONCLUSION}

More and more concerns about deep-water geohazards have been raised by the increasing amount of offshore hydrocarbon resources exploration and production. This paper illustrates an approach of submarine landslide management and mapping, which can help to identify landslides' features 
and processes in a time- and cost-efficient manner. And as a case study, we established a regional database to manage the geohazard data and gave an elementary mapping and interpretation of the geomorphologic features of landslides in Liwan3-1 gas field. With the integrated approach, more than one hundred landslides and overlapping failures are recognized. The landslides in the study area are featured as small and multiple superimposed failure scars. Most of slides are occurred in canyon walls, which were mainly triggered by brittle deformation. There are also some slide failures triggered by plastic deformation on the bottom of the canyons. The integrated manner is also helpful to provide fundamental information for further run-out analysis and geohazard risk assessment.

\section{FUTURE WORK}

This study is mainly focused on the seafloor geomorphologic features mapping and primary depiction for marine geohazard assessment based on bathymetric data and seismic profiles. Some detail and statistical analysis, including landslide runout analysis, area and volume computation, susceptibility and so on, should be implemented with GIS technology in the following work.

\section{CONFLICT OF INTEREST}

The authors confirm that this article content has no conflict of interest.

\section{ACKNOWLEDGEMENTS}

This research is supported by the sub-project 2011ZX05056-001 of "The Important Project of Science and Technology in Developing Great Oil \& Gas Field and Coal Bed Gas". We greatly appreciate Mr. Li Xinzhong, the general engineer of the Project, and Mr. Li Qingping, the chief scientist, from the Research Center of CNOOC for their help and support. We also thank Mr. Li Jianchang, the general manager, and Mr. Chen Keqin, the director, from the Department of Engineering of CNOOC.

\section{REFERENCES}

[1] B.G. McAdoo, "Mapping Submarine Slope Failures," In: D.J. Wright, and D.J. Bartlett, Eds. Marine and Coastal Geographical Information Systems, London: Taylor and Francis, 2000, pp. 189204.

[2] B.G. McAdoo, L.F. Pratson, and D.L. Orange, "Submarine landslide geomorphology, US continental slope," Marine Geology, vol. 169 , no. 1-2, pp. 103-136, Sep. 2000.
[3] V. Huhnerbach, D.G. Masson, and partners of the COSTAProject, "Landslides in the North Atlantic and its adjacent seas: an analysis of their morphology, setting and behavior," Marine Geology, vol. 213, no. 1-4, pp. 343-362, Dec. 2004.

[4] D.G. Masson, C.B. Harbitz, R.B. Wynn, G. Pedersen, and F. Løvholt, "Submarine landslides: processes, triggers and hazard prediction," Philosophical Transactions of the Royal Society a Mathematical Physical and Engineering Sciences, vol. 364, no. 1845, pp. 2009-2039, Aug. 2006.

[5] U.S. Ten Brink, E.L. Geist, and B.D. Andrews, "Size distribution of submarine landslides and its implications to tsunami hazard in Puerto Rico," Geophysical Research Letters, vol. 33, pp. 1-4, Jun. 2006.

[6] M.J.R. Gee, H.S. Uy, J. Warren, C.K. Morley, and J.J. Lambiase, "The Brunei slide: a giant submarine landslide on the North West Borneo Margin revealed by 3D seismic data," Marine Geology, vol. 246, no. 1, pp. 9-23, 2007.

[7] G. Cauchon-Voyer, J. Locat, and G. St-Onge, "Late-Quaternary morpho-sedimentology and submarine mass movements of the Betsiamites area, Lower St. Lawrence Estuary, Quebec, Canada," Marine Geology, vol. 251, no. 3-4, pp. 233-252, Jun. 2008.

[8] D.C. Twichell, J.D. Chaytor, U.S. ten Brink, and B. Buczkowski, "Morphology of late Quaternary submarine landslides along the US Atlantic continental margin," Marine Geology, vol. 264, no. 1-2, pp. 4-15, Aug. 2009.

[9] R. Leon, and L. Somoza, "GIS-based mapping for marine geohazards in seabed fluid leakage areas (Gulf of Cadiz, Spain)," Marine Geophysical Research, vol. 32, no. 1, pp. 207-223, Mar. 2011.

[10] Y.Q. Kou, "Landslide in the north of South China Sea," Exploitation of Ocean and Coastal Zone, vol. 7, pp. 48-52, Jul. 1990.

[11] J.R. Chen, "An analysis on seafloor stability of the Pearl River Mouth Basin," Journal of Tropic Oceanography, vol. 10, pp. 4957, May. 1991.

[12] W. Fen, Y. Shi, and L. Chen, "Research for Seafloor Landslide Stability on the outer Continental Shelf and the Upper Continental Slope in the Northern South China Sea," Marine Geology and Quaternary Geology, vol. 14, no. 2, pp. 82-93, Jun. 1994.

[13] C.W. Bao, and Y.K. Jiang, "Types and characteritics of potential subbottom geological hazards in nearshore zone of China," Tropic Oceanography, vol. 18, pp. 24-31, Jul. 1999.

[14] Y.B. Sun, S. Wu, Z. Wang, Q. Li, X. Wang, D. Dong, and F. Liu, "The geometry and deformation character of Baiyun Landslide," Marine Geology and Quaternary Geology, vol. 28, pp. 69-77, Dec. 2008.

[15] P. Yan, Y. Wang, and H. Zheng, "Characteristics of deep water sedimentation revealed by sub-bottom profiler survey over the Baiyun Sag-Southwest Dongsha island waters in the northern south China sea," Journal of Tropical Oceanography, vol. 30, pp. 115-122, Mar. 2011.

[16] J.J. Becker, D.T. Sandwell, W.H.F. Smith, J. Braud, B. Binder, J. Depner, D. Fabre, J. Factor, S. Ingalls, S.H. Kim, R. Ladner, K. Marks, S. Nelson, A. Pharaoh, R. Trimmer, J. Von Rosenberg, G. Wallace, and P. Weatherall, "Global Bathymetry and Elevation Data at 30 Arc Seconds Resolution: SRTM30 PLUS," Marine Geodesy, vol. 32, no. 4, pp. 355-371, Oct. 2009.

[17] IOC, IHO, and BODC, "Centenary Edition of the GEBCO Digital Atlas". CD-ROM, British Oceanographic Data Centre, Liverpool, U.K., 2003.

Received: December 15, 2014

Revised: January 04, 2015

Accepted: February 25, 2015

(C) Su et al.; Licensee Bentham Open.

This is an open access article licensed under the terms of the Creative Commons Attribution Non-Commercial License (http://creativecommons.org/licenses/by-nc/3.0/) which permits unrestricted, non-commercial use, distribution and reproduction in any medium, provided the work is properly cited. 